\title{
Correction to: Secukinumab: A Review in Psoriatic Arthritis
}

\author{
Hannah A. Blair ${ }^{1}$ \\ Published online: 15 April 2021 \\ (c) Springer Nature 2021
}

\section{Correction to: Drugs (2020) 81(4):483-494 https://doi.org/10.1007/s40265-021-01476-3}

The article Secukinumab: A Review in Psoriatic Arthritis, written by Hannah A Blair, was originally published electronically in SpringerLink on 4 March 2021 without open access. After publication in volume 81, issue 4, pages 483-494 Novartis Pharma AG, requested that the article be Open Choice to make the article an open access publication. Post-publication open access was funded by Novartis Pharma AG. This article is licensed under a Creative Commons Attribution-NonCommercial 4.0 International License, which permits any non-commercial use, sharing, adaptation, distribution and reproduction in any medium or format, as long as you give appropriate credit to the original author(s) and the source, provide a link to the Creative Commons licence, and indicate if changes were made. The images or other third party material in this article are included in the article's Creative Commons licence, unless indicated otherwise in a credit line to the material. If material is not included in the article's Creative Commons licence and your intended use is not permitted by statutory regulation or exceeds the permitted use, you will need to obtain permission directly from the copyright holder. To view a copy of this licence, visit http://creativecommons.org/licen ses/by-nc/4.0/.

The original article has been corrected.

Open Access This article is licensed under a Creative Commons Attribution-NonCommercial 4.0 International License, which permits any non-commercial use, sharing, adaptation, distribution and reproduction in any medium or format, as long as you give appropriate credit to the original author(s) and the source, provide a link to the Creative Commons licence, and indicate if changes were made. The images or other third party material in this article are included in the article's Creative Commons licence, unless indicated otherwise in a credit line to the material. If material is not included in the article's Creative Commons licence and your intended use is not permitted by statutory regulation or exceeds the permitted use, you will need to obtain permission directly from the copyright holder. To view a copy of this licence, visit http://creativecommons.org/licenses/by-nc/4.0/.
The original article can be found online at https://doi.org/10.1007/ s40265-021-01476-3.

Hannah A. Blair

demail@springer.com

1 Springer Nature, Mairangi Bay, Private Bag 65901, Auckland 0754, New Zealand 